\title{
DETERMINANTS OF CUSTOMER LOYALTY TO MOBILE PHONE BRANDS
}

\author{
Edith Onowe Odia, Simon Ayo Adekunle* \\ Department of Business Administration, Faculty of Management Sciences, University of \\ Benin, Benin City, Nigeria \\ edyy2002ng@yahoo.com \\ adeksim@yahoo.com
}

\begin{abstract}
This study empirically examined customer loyalty to mobile phone brands in Nigeria with specific objectives of establishing customers' preference for the different brands of mobile phone; ascertain the rationale for customer loyalty and preference for mobile phones; and examining the influence of demographic variables on customer loyalty to mobile phone usage. A survey research design with the use of questionnaire was adopted to generate the needed data for the study. The population of the study comprised users of mobile phones in the university community, ministries, and secondary schools in Benin City, Nigeria. Copies of questionnaire were administered to two hundred (200) respondents out of which one hundred and ninety-four (194) were returned and found useable. Statistical tools including simple percentage, mean, $t$-test and analysis of variance (ANOVA) were employed for data analysis through the use of Statistical Package for Social Sciences (SPSS 22.0). The study found that there is a significant relationship between respondents' demographics (gender, age and educational qualification) and customer loyalty at a 5\% level of significance. Based on the investigated factors influencing mobile phone purchases such as quality, functionality, cost, durability and ease of maintenance, the study revealed that Nokia, Blackberry and Samsung are the most preferred mobile phones in Nigeria. The study, therefore, recommends that manufacturers of mobile phones should ensure that their products are of good quality, durable, affordable, easy to repair and capable of performing multiple functions so that those customers who like using more than one phone with different functional varieties can be loyal to a particular brand.
\end{abstract}

Keywords: Brand loyalty, Customer, Durability, Mobile phones, Quality.

JEL classification: M3, M31, M310.

\section{Introduction}

The whole world has now become a global village where people can reach one another in different parts of the world with the help of modern technologies such as mobile phones within a short period (Aidoo and Nyamedor, 2008; Srinivasan, 2018). Mobile phones have evolved from analogue to digital (Jin, 2018). The first generation of mobile phones were analogue, but subsequent generations have been predominantly digital (Pascal, 2007). In the 1990s, analogue phones were deployed by Nigerian Telecommunications Limited (NITEL), the only national carrier then. Satellite phone was also available (Adeyinka, et al., 2007). However, these mobile phones were not accepted by the generality of Nigerians because they were not only expensive but also, they were seen as status symbols rather than a necessity (Pascal, 2007). The launching of a new mobile telecoms technology known as the Global System for Mobile communication (GSM) in Nigeria in 2001 transformed the telecommunication sector which has been instrumental to the rapid increase in telecommunications accessibility (Bakare and Gold, 2011). GSM dominated the digital

\footnotetext{
* Corresponding Author: Dr. Simon Ayo Adekunle
} 
cellular market with $70 \%$ of the market and more than 500 million subscribers in 169 countries in 2000 with worldwide mobile users of 2.13 billion and 4 billion in 2005 and 2011 respectively (Pascal, 2007).

Statistics record (Radicati, 2014) that as at 2004, there were over 5000 direct and 400,000 indirect employments the Tel-communication industry in Nigeria (Bakare and Gold, 2011; Adomi, 2006). This sector appeared to have improved the nation's GDP as its contributions increased from $0.32 \%$ in 2000 to $3.66 \%$ in 2009 (NCC, 2012) and generated over 200 billion Naira (Adeyinka et al., 2007). It is purported that Nigeria has the largest market (the Computer Village in Lagos) for GSM in Africa (Kenneth, 2007).

Mobile phones are "one of the modern telecommunication technologies that have emerged over the past decades to facilitate communication among people within and across countries" (Dziwornu, 2013, p.151). Nowadays, mobile phones are used by different individuals in society (Lipschultz, 2019) such as the office cleaner, auto mechanic, drivers, students, farmers, market women to the businessman and the Chief Executive Officer (CEO) of both private and public institutions in Nigeria. They perform varieties of functions among which are making and receiving calls, text messages, music player, multimedia messaging and Internet browsing, among others. There are several brands and sizes of mobile phone handsets with different ranges of prices and functionalities as well as network providers on the Nigerian market that render the aforementioned services.

In promoting the marketing concept of treating customers as kings, there is a need for mobile phone manufacturers to continuously pay adequate attention to the needs of their customers to make them loyal (Adomi, 2006). Satisfied customers are more likely to be loyal customers and give the firms a larger share of their businesses (Otto et al., 2019). Companies are realizing that losing a customer means losing more than a single sale; it means losing the stream of purchases that the customer would make over a lifetime of patronage (Kotler and Armstrong, 2010). It is on this basis that this study examines the factors affecting customer loyalty to mobile phone brands in Nigeria. Specifically, the study sought to establish customers' preference for the different brands of mobile phones; ascertain the rationale for customer loyalty and preference for mobile phones; and identify the demographic variables that influence customer loyalty to mobile phone brands.

\section{Review of Related Literature}

Brand loyalty is a deeply held commitment to re-buy a preferred brand of goods or services in the future despite situational influences and marketing efforts having the potential to cause switching behavior (Krivic and Loh, 2018). It exists when a customer, because of experience, is sufficiently satisfied with a particular brand that he or she buys that brand or with a retailer, he or she buys from when the need arises without considering other alternatives (Etzel, et al., 2007; Kotler and Keller, 2009; Agbaje, 2011). The concept of loyalty has admittance to the business context that is massively used in the field of marketing to describe the customer's willingness to continue patronizing a firm over the long term; it is emerging as the marketplace currency for the twenty-first century (Singh and Sirdeshmukh, 2000; Karunaratna, 2014). According to Anderson and Jacobsen (2000, p.65), "customer loyalty is the result of an organization creating a benefit for a customer so that they will maintain or increase their purchases from the organization." It is apparent that the success of a firm largely depends on its capability, not only to attract consumers towards its brand but also retain them in the long run.

Various authors at different times have identified several factors that influence customers' choice and loyalty to mobile phone brands across the globe. One of the pioneering studies on mobile phone choice by Riquelme (2001) examined how much self-knowledge consumers have when choosing between different mobile phone brands. The study was built on six key attributes such as telephone features, connection fee, access cost, 
mobile-to-mobile phone rates, call rates and free calls. The study revealed that consumers with prior experience with a product can predict their choices relatively well.

Karjaluoto, et al. (2005) examined factors affecting consumer choice of mobile phone in Finland. The study focused on factors that influence the intention to acquire new mobile phones on one hand and factors that influence mobile phone change on the other hand. The study classified the factors into seven categories namely innovative services, multimedia, design, brand and basic properties, outside influence, price and reliability. The study revealed that factor innovative services and factor multimedia were the most important factors that affect mobile phone choice. Also, technical problems were found to be the basic reason to change mobile phones among students while price, brand, interface, and properties were the most influential factors affecting the actual choice between brands.

Aidoo and Nyamedor (2008) explored the factors that determine the choice of mobile phone brand among residents of Kumasi metropolis in Ghana. The study revealed that reliable quality and user-friendliness are the two most important factors underlying the choice of brand of mobile phone. The study also found that 76 percent of the respondents owned a mobile phone and also most people did not use mobile phone because of its high cost. The analysis also revealed that Nokia is the most used mobile phone and the brand of mobile phones used by the consumer is associated with educational level attainment and occupational status of the consumer.

Singla and Bansal (2010) identified and compared key attributes that influence mobile phone purchasing between Sangrur and Ludhiana consumers in India. According to the authors, mobile phone users wanted their handsets to be loaded with multiple functions, entertainment is the most important among them. They wanted their mobile phones to be fully loaded with top-end features, but at the same time, they wanted all these at affordable costs. Similarly, the study conducted by Mokhlis and Yaakop (2012) examined seven independent dimensions namely innovative features, image, price, personal recommendation, durability and portable aspects, media influence, and post-sales service as different choice criteria in mobile phone selection among Malaysian consumers. The study found that the top three most important factors influencing consumer choice of mobile phone handsets were: innovative features, personal recommendation and price. It was recommended that the promotion of new mobile phone models should go beyond highlighting properties to highlighting what users can do with all the technical features.

In the study conducted by Saif, Razzaq, Amad, and Gul (2012) on the factors that affect Pakistani consumers in their mobile phone choice decision, four important factors such as price, size/shape, new technology features and brand name were examined. The study found that when selecting between different mobile phone handsets, consumers prefer well-known brands instead of no familiar brands. The study further shows that price does affect consumers' choice for a mobile phone but becomes a less important factor as consumers move from low monthly income to higher income earning consumers. The study also revealed that male respondents were more interested in the new technological developments in the mobile phone industry as compared to female respondents.

Dziwornu (2013) investigated the factors affecting mobile phone purchase decision in the Greater Accra Region of Ghana, using a binary logit regression model approach. Results from the study show that Nokia and Samsung phones were the two main brands of phones used by majority of the respondents interviewed. Also, the study revealed that advanced technology features such as internet browsing, durability and quality of mobile phone handsets the main factors that are likely to positively and significantly affect mobile phone purchase decisions. It was therefore recommended that manufacturers and marketers of mobile phone handsets should produce and market more durable and high-quality mobile phone handsets with modern technology features that are targeted at the educated youth. Adekunle and Ejechi (2018) examined how service quality measured by convenience, functionality and perceived usefulness impact on users' satisfaction and repurchase 
intention. Data were collected using 486 validly filled copies of questionnaire by smartphone users. The study found that convenience, functionality and perceived usefulness significantly influence users' satisfaction. The study also revealed that perceived usefulness significantly impacts on users' repurchase intention. The study concluded that users' repurchase intention is influenced by users' satisfaction and service quality.

Inegbedion and Obadiaru (2019) in their study on modeling brand loyalty using the Nigerian telecommunication industry found that $21 \%$ of the GSM users in the country will be loyal to MTN while Airtel will retain $27 \%$ of the total market. The study also reveals that Globacom and 9 Mobile will retain $35 \%$ and $1 \%$ of the market share respectively.

It can be observed from the review of previous studies that quality, recommendations by family and friends, durability, innovative services, multimedia, design, brand and basic properties, outside influence, price and reliability are the major factors that influence customers' choice and loyalty to mobile phone brands across the globe. This study, therefore, examined the opinions of customers on major attributes of mobile phones such as quality, cost, functionality, durability and ease of maintenance in Nigeria.

\section{Methodology}

The survey research design was adopted for this study. The population of the study comprised users of mobile phones in Benin City, Edo State, Nigeria. A sample of two hundred (200) mobile phone users were selected from the different stakeholders which include students, academic staff, non-academic staff and other business individuals working in the University community, ministry workers, secondary school teachers, among others. The copies of questionnaire used as a research instrument were administered in the Second Semester of 2012/2013 academic session when all the aforementioned stakeholders were fully on Campus for different academic and business activities at the Ugbowo Campus of the University of Benin. Also, seven popular brands of mobile phones in Nigeria namely: Nokia, Blackberry, Samsung, Tecno, LG, HTC and Sony Ericson were used for this study. The study obtained data from the primary source through questionnaire administration as a research instrument. The questionnaire consists of two (2) parts namely: respondents' demographics and questions that cover customers' loyalty, preference and rationale for a choice of mobile phone. Out of the two hundred (200) questionnaires administered to respondents, one hundred and ninety-four (194) were returned and found useable. The data collected were analyzed using different statistical tools such as frequency table, simple percentages, mean, t-test and analysis of variance (ANOVA) with the aid of Statistical Packages for Social Sciences (SPSS) software.

\section{Results and Discussions}

\subsection{Description of Company Profile}

This section presents the results that emanated from the data analysis in line with the research objectives as well as the discussion of findings. The respondents were asked where and how they obtained their phones to provide background information on the sources of mobile phones used by the respondents.

Table 1. Source of obtaining mobile phones among respondents

\begin{tabular}{|c|l|c|c|}
\hline $\mathrm{S} / \mathrm{N}$ & Source & Frequency & $\%$ \\
\hline 1 & Accredited distributors & 70 & 36.1 \\
\hline 2 & General market & 61 & 31.4 \\
\hline 3 & Gift from others & 63 & 32.5 \\
\hline \multicolumn{2}{|c|}{ Total } & 194 & 100 \\
\hline
\end{tabular}

Source: Authors' fieldwork 
The result reveals that majority of the sampled respondents either purchased their mobile phones from accredited distributors. This category accounts for $36.1 \% .61(31.4 \%)$ of the respondents obtained their phones from the general market place $32.5 \%$ of the respondents got their phone as a gift from someone/somewhere/friends.

\subsection{Customer preference for the different brands of mobile phones}

In establishing the mobile phone users' preference for the different brands of mobile phones, respondents were asked to indicate their preference for some selected popular brands of phones in Nigeria. The responses to the different questions are presented in Table 2:

Table 2. Preference for mobile phones

\begin{tabular}{|c|c|c|c|}
\hline $\mathbf{S} / \mathbf{N}$ & Variable/Brand of Phones & Frequencv & $\%$ \\
\hline \multicolumn{4}{|c|}{ Preferred mobile ohone(s) } \\
\hline 1 & Nokia & 97 & 49 \\
\hline 2 & Blackberrv & 44 & 22 \\
\hline 3 & Samsuna & 24 & 12 \\
\hline 4 & Tecno & 13 & 07 \\
\hline 5 & HTC & 14 & 07 \\
\hline 6 & Sonv Ericson & 04 & 02 \\
\hline 7 & LG & 04 & 02 \\
\hline & Total & $200^{*}$ & 100 \\
\hline
\end{tabular}

Note: * indicates that a respondent ticked more than one option

Source: Authors' fieldwork

Table 2 presents popular brands of phones in the market as at the time of the study and how they are preferred by the respondents. The result shows that Nokia, Blackberry and Samsung products are the most preferred and popular brands of mobile phones with $49 \%$, $22 \%, 12 \%$ respectively. The other brands such as Tecno, HTC, LG and Sony Ericsson were jointly preferred by only $17 \%$ of the entire respondents. The finding that Nokia, Blackberry and Samsung phones are the most preferred is consistent with Dziwornu (2013).

\subsection{Rationale for customer loyalty and preference for different mobile phones brands} In ascertaining the rationale for customer loyalty and preference for the different brands of mobile phones sampled for this study, respondents were asked to express their opinions on some factors such as durability, functionality of the brand, quality, cost and ease of maintenance that can influence customers to be loyal to a particular brand of mobile phone. The result is shown in Table 3 below:

Table 3. Customers' opinions on factors of mobile phones brands

\begin{tabular}{|c|c|c|c|c|c|c|c|c|c|c|c|c|}
\hline \multirow{2}{*}{$\begin{array}{l}\mathbf{S} / \\
\mathbf{N}\end{array}$} & \multirow{2}{*}{$\begin{array}{c}\text { Brand of } \\
\text { Phone }\end{array}$} & \multicolumn{2}{|c|}{ Durability } & \multicolumn{2}{|c|}{ Quality } & \multicolumn{2}{|c|}{$\begin{array}{c}\text { Functiona } \\
\text { lity }\end{array}$} & \multicolumn{2}{|c|}{$\begin{array}{l}\text { Easy to } \\
\text { Maintain }\end{array}$} & \multicolumn{2}{|c|}{$\begin{array}{c}\text { Product } \\
\text { Cost }\end{array}$} & \multirow{2}{*}{$\begin{array}{l}\text { Ran- } \\
\text { king }\end{array}$} \\
\hline & & Freq & $\%$ & Freq & $\%$ & Freq & $\%$ & Freq & $\%$ & Freq & $\%$ & \\
\hline 1 & Nokia & 69 & 30 & 57 & 25 & 38 & 17 & 46 & 20 & 20 & 09 & 1st \\
\hline 2 & Blackberry & 09 & 18 & 13 & 26 & 19 & 38 & 03 & 06 & 06 & 12 & 2nd \\
\hline 3 & Samsung & 11 & 24 & 14 & 31 & 12 & 27 & 06 & 13 & 02 & 04 & 3rd \\
\hline 4 & Tecno & 07 & 29 & 05 & 21 & 07 & 29 & 05 & 21 & 00 & 00 & 4th \\
\hline 5 & HTC & 02 & 13 & 04 & 25 & 05 & 31 & 03 & 19 & 02 & 13 & 5 th \\
\hline 6 & Sony & 04 & 36 & 05 & 45 & 00 & 00 & 01 & 09 & 01 & 09 & 6th \\
\hline 7 & $\mathrm{LG}$ & 02 & 33 & 02 & 33 & 01 & 17 & 01 & 17 & 00 & 00 & 7th \\
\hline \multicolumn{2}{|c|}{ Total (Freq) } & \multicolumn{2}{|c|}{104} & \multicolumn{2}{|c|}{100} & \multicolumn{2}{|c|}{82} & \multicolumn{2}{|c|}{65} & \multicolumn{2}{|c|}{31} & \\
\hline \multicolumn{2}{|c|}{ Ranking } & \multicolumn{2}{|c|}{$1^{\text {st }}$} & \multicolumn{2}{|c|}{$2^{\text {nd }}$} & \multicolumn{2}{|c|}{$3^{\text {rd }}$} & \multicolumn{2}{|c|}{$4^{\text {th }}$} & & \\
\hline
\end{tabular}

Source: Authors' fieldwork 
Respondents were asked to use the aforementioned factors to rate the different brands of mobile phones selected for this study. The result as shown in Table 3 reveals that Nokia, Blackberry and Samsung are the most preferred mobile phones in Nigeria as they were ranked first, second and third respectively. Others such as Tecno, HTC, Sony Ericson and LG were ranked fourth, fifth, sixth and seventh respectively. In the same vein, Table 2 also reveals that durability and quality are the main factors that promote customer loyalty to the brand of the phone(s) they use as these factors were ranked first and second respectively. Functionality, ease of maintenance and product costs were ranked third, fourth and fifth respectively.

This study found that product quality and durability are the major factors that keep customers loyal to a particular brand of a mobile phone. This finding is in agreement with the study of Aidoo and Nyamedor (2008) that found that reliable quality of the mobile phone is the most important factor considered by users. Also, product functionality is found to be an important factor in this study. This finding agrees with that of Karjaluoto, et al (2005) that consumers purchase new phones because their existing one's capacity is not appropriate. Importantly also, this study revealed that product cost was not a major factor considered by customers to make them loyal. This finding is supported by studies conducted by Aidoo and Nyamedor (2008), Singla and Bansal (2010), and Saif, et al, (2012) that found that mobile phone users wanted their mobile phones to be fully loaded with top-end features, but at the same time they wanted all these at affordable costs. However, Pakola, et al. (2007) found that price was regarded as the most important motive affecting the decision to purchase the current mobile phone model for consumers in Finland.

Table 4. Number of phones and manufacturers' information

\begin{tabular}{|c|l|c|c|}
\hline $\mathbf{S} / \mathbf{N}$ & Variable & Frequency & Percentage \\
\hline 1 & Respondents with more than one phone & 107 & 55.15 \\
\hline 2 & Respondents with only one phone & 87 & 44.85 \\
\hline \multicolumn{2}{|c|}{ Total } & 194 & 100 \\
\hline 1 & Phones from the same manufacturers & 32 & 29.91 \\
\hline 2 & Phones from different manufacturers & 75 & 70.09 \\
\hline \multicolumn{2}{|l|}{ Total } & 107 & 100 \\
\hline
\end{tabular}

Source: Authors' fieldwork

Table 4 above reveals that 107 (55.15\%) of the sampled respondents use more than one phone. 87 out of the 194 respondents used only one phone. This latter category accounts for only $44.85 \%$ of the total respondents used for this study. In providing more information on how loyal a customer is to the product of a particular company, the respondents that indicated that they have more than one phone were asked whether the phones were produced by the same manufacturer or company. The result shows that only 32 out of the 107 respondents purchased their phones from the same manufacturer. This accounts for only $29.91 \%$ of the entire respondents. $70.09 \%$ of the respondents did not patronize the same manufacturer in getting the other phones.

\subsection{Influence of respondents demographics on their loyalty to a brand of phone}

This section presents the analysis of consumers' demographic influences on mobile phone brand loyalty using simple percentages, T-Test and analysis of variance (ANOVA). Also, post hoc analysis was conducted using Student-Newman-Keuls (S-N-K) Procedure. 
Table 5. Gender influences on customer loyalty

\begin{tabular}{|c|c|c|c|c|c|c|c|c|c|c|}
\hline$S / N$ & Sex & Yes & $\%$ & No & $\%$ & Total & $\%$ & t-value & $\mathrm{p}$-value & Decision \\
\hline 1 & Male & 23 & 71.9 & 26 & 34.7 & 49 & 45.8 & \multirow{3}{*}{-2.979} & \multirow{3}{*}{0.000} & \multirow{3}{*}{ Significant } \\
\hline 2 & Female & 9 & 28.1 & 49 & 65.3 & 58 & 54.2 & & & \\
\hline \multicolumn{2}{|c|}{ Total } & 32 & 100 & 75 & 100 & 100 & 100 & & & \\
\hline
\end{tabular}

Source: Authors' fieldwork

The t-Statistic of -2.979 with the $p$-value of 0.004 reveals that there is a significant difference in customer loyalty between male and female mobile phone users. Table 5 further shows that majority of the respondents that have more than one phone are female as this group accounts for $54.2 \%$ while their male counterpart accounts for $45.8 \%$. Notwithstanding, more females use multiple phones, loyalty index of 0.762 (23 out of 32 ) indicates that the males are more loyal with index of 0.28 . Of the 49 -total number of males using multiple phones, $46.9 \%$ were found to be loyal while only a meager $15.5 \%$ (9) of the 58 female respondents using multiple phones were found to be loyal in the selection of cell phones. This finding aligns with the studies of Karjaluoto, et al (2005), Ogunyemi (2010), and Balakrishnan and Raj (2012) that found that differences exist between males and females concerning what attracts them to buy a particular mobile phone.

Table 6. Age influences on customer loyalty

\begin{tabular}{|c|c|c|c|c|c|c|c|c|c|c|}
\hline $\mathbf{S} /$ & Age & Yes & $\%$ & No & $\%$ & Total & $\%$ & F-Value & P-value & Decision \\
\hline 1 & $18-30$ & 29 & 90.6 & 40 & 53.3 & 69 & 64.5 & \multirow{4}{*}{7.998} & \multirow{4}{*}{0.001} & \multirow{4}{*}{ Significant } \\
\hline 2 & $31-40$ & 1 & 3.1 & 25 & 33.3 & 26 & 24.3 & & & \\
\hline 3 & $\begin{array}{l}41 \text { and } \\
\text { Above }\end{array}$ & 2 & 6.3 & 10 & 13.3 & 12 & 11.2 & & & \\
\hline \multicolumn{2}{|c|}{ Total } & 32 & 100 & 75 & 100 & 100 & 100 & & & \\
\hline
\end{tabular}

Source: Authors' fieldwork

Also, the results reveal that most of the respondents fall between the age brackets of $18-30$ years old. This group account for $64.5 \%$ of the entire respondents. This is followed with respondents between the age of $31-40$ years old while respondents that are 41 years old and above have the least percentage. The percentages of these categories are $24.3 \%$ and $11.2 \%$ respectively. The analysis of variance (ANOVA) results with F-Statistic of 7.998 and $\mathrm{p}$-value of 0.001 shows that there is a significant difference between respondents' age and their loyalty to the brands of mobile phones. Of the 69-total number of respondents age between $18-30$ years using multiple phones $42 \%$ (29) were found to be loyal. For age between $31-40$ years, only $3.8 \%$ (1) of the multiple phone holders were discovered to be loyal. Lastly, of the 12 respondents, age above 40 years old users of multiple phones, only $16.7 \%$ (2) were found to be loyal. Further analysis revealed that $90.6 \%$ (29) of the loyal 32 $(30 \%)$ were between the age of $18-30$ years while only a very small proportion $3.15 \%$ (1) of loyal users are between ages of $31-40 y e a r s$. Lastly, only (2) $6.25 \%$ of loyal users are ages 41 and above.

Table 7. Loyalty to mobile phone selection and respondents' age: Multiple range tests based on Student-Newman-Keuls (S-N-K) procedure

\begin{tabular}{|l|ll|}
\hline & $\begin{array}{l}\text { More } \\
\text { Loyal } \\
\text { Users }\end{array}$ & $\begin{array}{l}\text { Less } \\
\text { Loyal } \\
\text { Users }\end{array}$ \\
\hline INDEX & Group 1 & Group 2 \\
\hline Mobile & Users between $18-30$ years & Users age above 40 yrs \\
Phone & Users age above 40 & Users between 31 to 40 yrs \\
\hline
\end{tabular}

Source: Authors' fieldwork 
It could be seen from the post hoc (S-N-K) analysis that the respondents between $18-30$ are as loyal as those above 40 years of age, but are not as loyal as those between $31-40$ years of age.

Table 8. Educational influences on customer loyalty

\begin{tabular}{|c|c|c|c|c|c|c|c|c|c|c|}
\hline $\mathbf{S} / \mathbf{N}$ & Education & Yes & $\%$ & No & $\%$ & Total & $\%$ & $\begin{array}{c}\text { F-val } \\
\text { ue }\end{array}$ & $\begin{array}{c}\text { P-val } \\
\text { ue }\end{array}$ & Decision \\
\hline 1 & $\begin{array}{l}\text { WASSCE/ } \\
\text { NECO }\end{array}$ & 21 & 65.6 & 17 & 22.7 & 38 & 35.5 & \multirow[t]{4}{*}{10.652} & \multirow[t]{4}{*}{0.000} & \multirow[t]{4}{*}{ Significant } \\
\hline 2 & HND/B.Sc & 9 & 28.1 & 44 & 58.7 & 53 & 49.5 & & & \\
\hline 3 & M.Sc/PhD & 2 & 6.3 & 14 & 18.6 & 16 & 15 & & & \\
\hline \multicolumn{2}{|l|}{ Total } & 32 & 100 & 75 & 100 & 107 & 100 & & & \\
\hline
\end{tabular}

Source: Authors' fieldwork

Lastly, respondents with HND/B.Sc dominated the sample as this group accounts for $49.5 \%$. This is followed by respondents with WASSCE/NECO and M.Sc/Ph.D with $35.5 \%$ and $15 \%$ respectively. In the same vein, the analysis of variance (ANOVA) results with F- Statistic of 10.652 and $p$-value of 0.000 shows that respondents' loyalty to the brands of mobile phones is dependent on their educational qualification. Still, on the educational factor, $55.3 \%(21)$ of the 38 WASSCE/NECO holders who use multiple phones were found to be loyal, while $17 \%$ (9) of the $53 \mathrm{HND} / \mathrm{B}$.Sc holders were discovered to be loyal, only $12.5 \%$ (2) of the 16 M.Sc./PhD holders were loyal in the selection of mobile cell phones.

The result of the Student-Newman-Keuls (S-N-K) post hoc test ranked holders of WASSCE/NECO as the more loyal group while HND/B.Sc holders and MSc/PhD were ranked in group two as the less loyal users of cell phones.

Table 9. Loyalty to mobile phone selection and respondents' education: Multiple range tests based on Student-Newman-Keuls (S-N-K) procedure

\begin{tabular}{|c|c|c|}
\hline & $\begin{array}{l}\text { More } \\
\text { Loyal } \\
\text { Users }\end{array}$ & $\begin{array}{l}\text { Less } \\
\text { Loyal } \\
\text { Users }\end{array}$ \\
\hline INDEX & Group 1 & Group 2 \\
\hline $\begin{array}{l}\text { Mobile Phone } \\
\text { Selection }\end{array}$ & WASSCE/NECO holders & $\begin{array}{l}\text { HND/B.Sc holders } \\
\text { MSc/PhD holders }\end{array}$ \\
\hline
\end{tabular}

Source: Authors' fieldwork

The result of the S-N-K post hoc ranked holders of WASSCE/NECO in group 1 as the more loyal while HND/B Sc holders and M Sc/PhD were ranked in group two as the less loyal users of cell phones.

\section{Conclusion}

Mobile phones are gaining rapid acceptance among different individuals in the society such as the office cleaner, drivers, auto mechanic, students, market women to the businessman and the Chief Executive Officer (CEO) of both private and public institutions in Nigeria. The rapid acceptance and usage of mobile phones in Nigeria is positioning the manufacturing firms and other stakeholders in the business in a strategic way to maximize profit. However, for firms manufacturing mobile phones as well as their dealers to keep on maximizing profit, regular and continuous patronage must be guaranteed by customers. This will enhance their survival and growth. The orientation of some business organizations is that because they are opened for transaction and they have what the customers may need, is enough for 
customers to come in and continuously trade or do business with them. But unknown to so many organizations that there are so many factors, influences and other considerations that make customers patronize them. It is on this premise that this study empirically examined customer loyalty to mobile phones brand in Nigeria. The study identified some demographic variables such as gender, age and educational qualifications and found that the variables significantly influence customer loyalty. Also, an empirical analysis of factors influencing mobile phones purchases such as quality, functionality, cost, durability and ease of maintenance revealed that Nokia, Blackberry and Samsung are the most preferred mobile phones in Nigeria.

\section{Recommendations}

Based on the research findings, the study, therefore, recommends as follows. First, manufacturers of mobile phones should ensure that their products are of good quality, durable, affordable, easy to repair and capable of performing multiple functions. Second, manufacturers of mobile phones should produce phones that have different features and functions that can serve multiple purposes so that those customers who like using more than one phone with different functional varieties can be loyal to a particular brand. Third, the use of distributors who have good advertising and publicity capacities and also have large networks of sales points should be given priority so that their brand can be easily accessed as this would help maintain a good image and enhance customer loyalty. Fourth, cell phone manufacturers and marketers should target or focus more on the male youth with a low educational background as they were found to be more loyal in the use of a particular brand of phone. Finally, the managerial implication of this study is that it will help manufacturers and marketers of mobile phone products to know the product attributes that can make their present and potential customers to be loyal and therefore redesign their products to meet the needs and aspirations of their target markets.

\section{References}

Adekunle, S.A. and Ejechi, J.O., 2018. Modelling repurchase intention among smartphones users in Nigeria. Journal of Modelling in Management, 134, pp.794-814.

Adeyinka, T., Ajiboye, J.O., Adu, E.O. and Wojuade, J.I., 2007. Stakeholders' perceptions of the impact of GSM on Nigeria rural economy: Implication for an emerging communication industry. Journal of Information Technology Impact, 7 (2), pp.131-144.

Adomi, E.E., 2006. Mobile phone usage patterns of library and information science students at Delta State University, Abraka, Nigeria. Electronic Journal of Academic and Special Librarianship, 7 (1), pp.1-11.

Agbaje, J. E. 2011. Customer satisfaction and customer loyalty in the transport industry. (B.Sc Project, Department of Business Administration, University of Benin, Benin City).

Aidoo, E., and Nyamedor, B. 2008. A study on factors that determine the choice of brands of mobile phone: A case study in the Kumasi Metropolis. (B.Sc. Project, Department of Mathematics and Statistics, University of Cape Coast).

Anderson, H. and Jacobsen, P.N., 2000. Creating loyalty: Its strategic importance in your customer strategy. Customer Relationship Management, 55, pp. 55-67.

Bakare, A.S., 2011. Estimating the impacts of global system for mobile telecommunication (gsm) on income, employment and transaction cost in Nigeria. Journal of Economics and International Finance, 3 (1), pp.37-45.

Balakrishnan, V. and Raj, R.G., 2012. Exploring the relationship between urbanized Malaysian youth and their mobile phones: A quantitative approach. Telematics and Informatics, 29 (3), pp.263-272. 
Dziwornu, R.K., 2013. Factors affecting mobile phone purchase in the greater Accra region of Ghana: a binary logit model approach. International Journal of Marketing Studies, 5 (6), p.151.

Etzel, M. J., Walker, B. J., and Stanton, W. J. 2007. Marketing (4 ${ }^{\text {th }}$ edition). New York: McGraw-Hill//rwin Inc.

Inegbedion, H. and Obadiaru, E., 2019. Modelling brand loyalty in the Nigerian telecommunications industry. Journal of Strategic Marketing, 27 (7), pp.583-598.

Jin, D.Y., 2018. Evolution of Korea's mobile technologies: a historical approach. Mobile Media and Communication, 6 (1), pp.71-87.

Karjaluoto, H., Karvonen, J., Kesti, M., Koivumäki, T., Manninen, M., Pakola, J., Ristola, A. and Salo, J., 2005. Factors affecting consumer choice of mobile phones: Two studies from Finland. Journal of Euromarketing, 14 (3), pp.59-82.

Karunaratna A.C. 2014. Services quality and customer loyalty: Adequacy of SERVQUAL model. Global Journal of Commerce and Management Perspective, 3 (4), pp. 20-26

Kenneth, O. N. 2007. The impact of GSM mobile phones on Nigeria, Publication of Ezine Articles, [online] Available at: http://www.ezinearticles.com.Accessed [25 August 2014]

Kotler, P., and Armstrong, G. 2010. Principles of marketing, $13^{\text {th }}$ Edition. New Jersey: Pearson Prentice Hall

Kotler, P., and Keller, K. L. 2009. Marketing management (12 ${ }^{\text {th }}$ edition). New Jersey: Pearson Education Inc.

Krivic, S.J. and Loh, A., 2018. Factors relating to brand loyalty of a fitness health club franchise business in Vienna, Austria. International Research e-journal on Business and Economics, 2 (2), p.56-71.

Lipschultz, J.H., 2019. Social Media Measurement and Management: Entrepreneurial Digital Analytics. Routledge.

Mokhlis, S., and Yaakop, A. Y. 2012. Consumer choice criteria in mobile phone selection: An investigation of Malaysian University students. International Review of Social Sciences and Humanities, 2 (2), pp.203-212.

Ogunyemi, O. 2010. Consumption and (in) appropriate use of mobile phone among teenage Africans in the UK. Lincolnshire, England.

Otto, A.S., Szymanski, D.M. and Varadarajan, R., 2020. Customer satisfaction and firm performance: insights from over a quarter century of empirical research. Journal of the Academy of Marketing Science, 48, pp.543-564. Retrieved from: https://link.springer.com/content/pdf/10.1007/s11747-019-00657-7.pdf

Pakola, J., Pietilä, M., Svento, R., and Karjaluoto, H. 2007. An investigation of consumer behaviour in mobile phone markets in Finland. Submission to 32rd EMAC Conference, Track: New Technologies and E-Marketing.

Pascal, O. 2007. Nigeria: Mobile phone series. Retrieved from: http://www.naijatechguide.com/2007/10/nigeria-mobile-phone-series.html

Radicati, S., 2014. Mobile statistics report 2014-2018: executive summary. The Radicati Group, Inc., Palo Alto, USA. https://scholar.google.com/scholar?hl=en\&as sdt=0\%2C5\&q=Radicati\%2C+S. $\% 2 \mathrm{C}+$ 2018.+Mobile+statistics+report\%2C+2014-2018.+Palo+Alto\%2C+CA\%3A+The+Radicati+ Group\%2C+Inc.\&btnG=\#d=gs cit\&u=\%2Fscholar\%3Fq\%3Dinfo\%3A9V1dRZBu4hAJ\%3As cholar.google.com\%2F\%26output\%3Dcite\%26scirp\%3D1\%26hl\%3Den

Riquelme, H. 2001. Do consumers know what they want? Journal of Consumer Marketing, 18 (5), pp.437-448.

Saif, N., Razzaq, N., Amad, M., and Gul, S. 2012. Factors affecting consumers' choice of mobile phone selection in Pakistan. European Journal of Business and Management, 4 (12), pp.16-26. 
Singh, J., and Sirdeshmukh, D. 2000. Agency and trust mechanisms in consumer satisfaction and loyalty judgements. Journal of the Academy of Marketing Science, 28, pp.150-167.

Singla, S., and Bansal, S. 2010. A study on the factors affecting choice criteria of consumers for mobile handsets: A comparative analysis in Ludhiana and Sangrur Districts. Asian Journal of Management Research, 2 (1), pp.443-456.

Srinivasan, R. (2018). Whose global village? Rethinking how technology shapes our world. NYU Press.

\section{Bio-note}

Dr. (Mrs) Odia, E. O. is an Associate Professor in the Department of Business Administration at the University of Benin, Benin City, Nigeria. Her research area includes branding, green marketing, consumer behaviour, and gender issues. Before joining University of Benin in 2011, she acted as the HOD, Department of Accounting/Business Administration, Benson Idahosa University. She is an Associate Examiner for the National Open University of Nigeria (NOU) as well as an Assessor for Institute of Chartered Accountant of Nigeria (ICAN). She is a Member of The Academy of Management Nigeria and Organisation of Women in Science for Developing Countries (OWSD).

Dr. Simon Ayo Adekunle is a First Class Honours graduate of Business Administration in the Department of Business Administration, University of Benin, Benin City, Nigeria. He is a Lecturer and Certified Data Analyst. Adekunle has published in reputable international journals such as African Journal of Management and Economic Studies, Journal of Modelling in Management, Management of Environmental Quality: An International Journal and so on. He has reviewed for Journal of Modelling in Management, International Journal of Organizational Analysis, Management Sciences Review among others. He is currently the Business Editor of Nigeria Journal of Business Administration - a journal domiciled in the Department of Business Administration, University of Benin. His research interest and areas of specialization are operations management, risk management, corporate sustainability and marketing. 